\title{
Safety and efficacy of stem cell therapy for treatment of neural damage in patients with multiple sclerosis
}

\author{
Mohammadmahdi Jafarzadeh Bejargafshe ${ }^{1}$, Mohammad Hedayati ${ }^{2}$, Sahar Zahabiasli ${ }^{3}$, Eisa Tahmasbpour ${ }^{4}$, \\ Saeed Rahmanzadeh ${ }^{5}$, Amir Nejad-Moghaddam ${ }^{6}$ \\ ${ }^{1}$ Young Researchers and Elite Club, Science and Research Branch, Islamic Azad University, Tehran, Iran; ${ }^{2}$ Department of Cell and Molecular Biology, \\ ${ }^{3}$ Department of Plantprotection, Rasht Branch, University of Guilan, Rasht, Iran; ${ }^{4}$ Laboratory of Regenerative Medicine \& Biomedical Innovations, \\ ${ }^{5}$ Enzyme Technology Lab, Genetics \& Metabolism Research Group, Pasteur Institute of Iran, Tehran, Iran; ${ }^{6}$ Marine Medicine Research Center, \\ Baqiyatallah University of Medical Sciences, Tehran, Iran \\ Contributions: (I) Conception and design: E Tahmasbpour, A Nejad-Moghadam; (II) Administrative support: None; (III) Provision of study materials \\ or patients: None; (IV) Collection and assembly of data: MJ Bejargafshe, M Hedayati, S Zahabiasli; (V) Data analysis and interpretation: MJ \\ Bejargafshe, M Hedayati, S Zahabiasli; (VI) Manuscript writing: All authors; (VII) Final approval of manuscript: All authors. \\ Correspondence to: Dr. Amir Nejad-Moghaddam. Marine Medicine Research Center, Baqiyatallah University of Medical Sciences, Tehran, Iran. \\ Email: mab.biology@gmail.com.
}

\begin{abstract}
Multiple sclerosis (MS) is a multifocal inflammatory disease that involves the central nervous system and associated with limbs paralysis and serious problems in sensation, limbs, visual and sphincter. This disease is a result of autoimmune mechanism in which autoantibodies target the self-myelin antigens and cause demyelination. Because of the myelin dysfunction, MS is clinically identified with neurological disabilities. Furthermore, it can be entered into the progressive phase because of irreversible neurodegeneration and axons damage. Unfortunately, there is no effective therapeutic method for this disease and current medications have been focused on amelioration of symptoms and chronic inflammation. Although current immunotherapies ameliorate the reactivity of autoimmune anti-myelin and MS relapse rate, there is no approved method for improvement of the disease progression and repairing of the damaged myelin. Therefore, finding an appropriate clinical treatment for improvement of neurological damages in MS patients is essential. Mesenchymal stem cells (MSCs) are multipotent cells with high proliferative and self-renewal capacities, as well as immunomodulatory and neuroregenerative effects. Bone marrow and adipose tissues derived MSCs have been considered for the treatment of different diseases because not only they can be easily isolated from these tissues, but also a patient can be served as a donor for himself without the risk of rejection. More importantly, autologous MSCs carry a safer pattern without the risk of malignant transformation. Here, we will discuss the effectiveness of MSCs therapy for MS patients by reviewing of clinical trials.
\end{abstract}

Keywords: Multiple sclerosis (MS); mesenchymal stem cells (MSCs); cell-based therapy; inflammation

Received: 11 August 2019; Accepted: 08 October 2019; Published: 27 December 2019.

doi: $10.21037 /$ sci.2019.10.06

View this article at: http://dx.doi.org/10.21037/sci.2019.10.06

\section{Introduction}

Multiple sclerosis (MS) is a progressive nervous disease which is associated with chronic inflammation of the central nervous system (CNS) and subsequently axonal loss and myelin damage (1). Although multiple factors are correlated to the MS development and progression, uncontrolled response of immune system to myelin protein is the key pathogenic event in this process (2). The incidence of this neurodegenerative disease in females is higher than in males. It usually occurs in individuals between the ages of 20 and 30 years. Recent study has reported that more than 2.5 million of people throughout the world 
have MS disease (3). Unfortunately, there is no definitive treatment for MS patients and current medications are focused on amelioration of symptoms and chronic inflammation. Furthermore, drugs with immunomodulatory and immunosuppressant properties serve as a diseasemodifying agent and provide partial efficacy to ameliorate autoimmune reactions (4). Therefore, many studies have focused on molecular mechanisms of MS pathogenesis and its therapeutic strategies. Recent evidence has suggested that an appropriate treatment include the modulation or suppression of aggressive immune response, protection of neurons and axons against degeneration process, as well as improvement of repair or remyelination (5).

Recent investigation has revealed that mesenchymal stem cells (MSCs) can modulate the immune response in MS patients (6). Some studies have suggested the effectiveness of different stem cell types such as hematopoietic stem cells, cord blood and embryonic stem cells for neuroregeneration in these patients $(7,8)$. The clinical application of stem cells against different diseases is rapidly increasing due to their effectiveness and safety properties $(9,10)$. Many clinical trial studies have investigated clinical applications of MSCs and haematopoietic stem cells (HSC) (11) because these stem cells can be easily isolated from peripheral blood, adipose and bone marrow tissues, as well as umbilical cord (UC) blood and placenta (12). They can be extracted from a small amount of adipose or bone marrow tissues and expanded in culture media to create a large population of cells for cell-based therapy (13). Experimental studies showed that intravenous administration of MSCs has immune suppressive effect and ameliorates autoimmune diseases (14). It is also shown that MSCs transplantation significantly improves the clinical outcomes of MS in experimental autoimmune encephalomyelitis (EAE) models (15). Although recent investigations have reported the safety and effectiveness of stem cells for MS therapy, the actual underlying cellular and molecular mechanism of this event is not well-understood. Upon intravenous injection, MSCs are able to traffic into the brain lesions and improve the survival rate of brain cells. Some studies demonstrated axonal neuroprotection after MSCs therapy which is probably conducted via the synthesis of neurotrophic factors, and also immunomodulatory properties of MSCs (16). For these reasons, many studies are investigating the effectiveness of stem cells in treatment of human neurodegenerative diseases such as MS.

\section{MS types, signs and current treatments}

MS can be divided into four main categories with different symptomatic observations, including (I) relapsing-remitting MS (RRMS), (II) primary progressive MS (PPMS), (III) secondary progressive MS (SPMS), and (IV) progressive relapsing MS (PRMS) (1). The incidence of the RRMS is higher than the other types and associated with worsening attacks of neurological function. Nearly $85 \%$ of the MS patients are usually diagnosed with PRMS during their initial examinations. SPMS is a follow-up transition phase after RRMS (17). This is associated with progressive and continuous worsening of neurological damage and found in about $10 \%$ of the cases. PRMS is the least common MS types which is associated with continuous progression of the disease with occasion exacerbations along the way (17). The clinical signs and symptoms of MS are different from person to person. Eyes are usually the first and most commonly involved organs. Some patients may develop sensory and motor problems in hands and legs such as stinging, numbness, tingling, and difficulty in walking. Tinnitus or hearing impairments can be also found in these cases. The feeling of repeated urination, urine retention, incontinence in urination, and the loss of sexual ability are the other problems in MS patients. Furthermore, anxiety, depression, muscles pain, and difficulty speaking (18).

Currently, there are several medications for MS treatment (19). Methyl prednisolone (solomudrol or depomedrol), prophyrol, and betamethasone are commonly used for the disease control in these patients (20). More than 30 different drugs such as amantadine and baclofen are available to control the disease symptoms. Interferon beta (Avenx A), interferon $\beta 2$ ( $\beta$-bronchodilated B), and glutaramasterate (Copaxone) are the most common medicines for the control of the disease progression. The other therapeutic methods for MS patients include occupational therapy, physiotherapy, speech and massage therapies and (21-23).

Unfortunately, the current medications for MS are not efficient to target the deleterious effects of immune reactions (24). An ideal therapeutic strategy for MS treatment should ameliorate or suppress the autoimmune responses, protect neurons and axons against degeneration process, and improve repair and remyelination. Recent evidences have suggested that stem cells, especially adult 
MSCs, can modulate the immune response in various diseases (25). Induced pluripotent stem cells (iPSCs) are another type of stem cells that have the ability to modulate the autoimmune responses in CNS and induce remyelination and repairing (26). However, the use of iPSCs has not been seen in any of the clinical trials and, thereby, further investigations are essential on the effectiveness and safety these cells. In the following parts, we will review the significance of stem cells in MS therapy by reviewing the available clinical trials.

\section{Clinical trials for MS}

Stem cell-based therapy has recently provided a hope for treatment of MS patients. It is now considered as a most preferred and noninvasive method for treatment of different diseases (26). Stem cells have the unique ability to be differentiated to multiple cell types. This potential property of stem cell has increased its clinical applications (27). Thanks to the new technologies, stem cells can easily be isolated from different sources of the body, especially from adipose and bone marrow tissues (28). Upon stem cells injection into the cerebrospinal fluid (CSF) of the spinal cord, they can be differentiated into neuronal precursor cells and compensate the lost brain function (Figure 1). There are some clinical studies that investigated the effectiveness and safety of stem cells, particularly MSCs, in MS treatment.

\section{MSCs}

MSCs are multipotent and self-renewing stem cells that are able to be differentiated into several cell types such as chondrocytes, cardiomyocytes, osteocytes, adipocytes, hepatocytes, and neurons (29,30). They are often isolated from different tissues such as adipose, bone marrow and UC tissues (31). They regulate the immune response via the inhibition of $\mathrm{T}$ cells proliferation and protect damaged tissues via the paracrine mechanisms. Table 1 summarizes a list of up-going and completed clinical studies that investigated the effectiveness and safety of MSCs in MS treatment. The results have revealed that MSCs injection safely decreases the brain lesions and disease severity and consequently improves the quality of life in these patients.

\section{Bone marrow-derived MSCs}

Bone marrow tissue is an important source of MSCs which are essential for blood cells production (33). MSCs derived for bone marrow tissue have the ability to be differentiated into several cell types due to their multipotential properties. Intravenous administration of these MSCs is now considered as a safe and novel therapeutic tool for MS therapy. So far, several clinical trials evaluated the effectiveness of bone marrow derived MSCs in MS disease treatment (Table 2). Several investigations revealed that injection of bone marrow-derived autologous MSCs improves the disease severity, cognitive function and quality of life of MS patients through the neuroprotective and antiinflammatory properties (35).

\section{Adipose-derived MSCs (ADMSCs)}

Human adipose-derived stem cells (ASCs) have been extensively applied in stem cell research. These cells can be isolated from adipose tissue through the enzymatic digestion. They are also clinically used in tissue engineering and reconstruction, as well as in cell-based therapies. Experimental studies revealed that ASCs can differentiate into myelin-producing cells and compensate myelin loss in MS disease models (40,41). ASCs have been frequently used in clinical studies involving both autologous and allogeneic models. Several studies have reported that injection of ADMSCs is safe without any adverse effects (42). Fat cells are abundant in different tissues, especially in abdominal tissue and hip area and, therefore, they can be easily and safely isolated from substantial tissues by liposuction method. In a recent clinical trial study on 34 patients who underwent lipectomy for ADMSCs collection, only one serious adverse event was reported (12). Several lines of studies considered the effect of ADMSCs in MS treatment (Table 3). The results of these clinical studies showed that ADMSCs therapy is a safe method which improves MS disabilities such as sexual problems and social activities in these patients.

\section{UCMSCs}

UC is a perinatal and easily attainable tissue which can be used as a significant source of stem cells without ethical problems (43). MSCs are isolated from different parts of the UC such as Wharton's jelly. MSCs derived from Wharton's Jelly have higher proliferative and expansive ability, as well as immunosuppressive and therapeutic activity compared to the other adult stem cells $(44,45)$. Only a few clinical trial studies reported the effectiveness of placenta-derived MSCs or intravenous injection of 


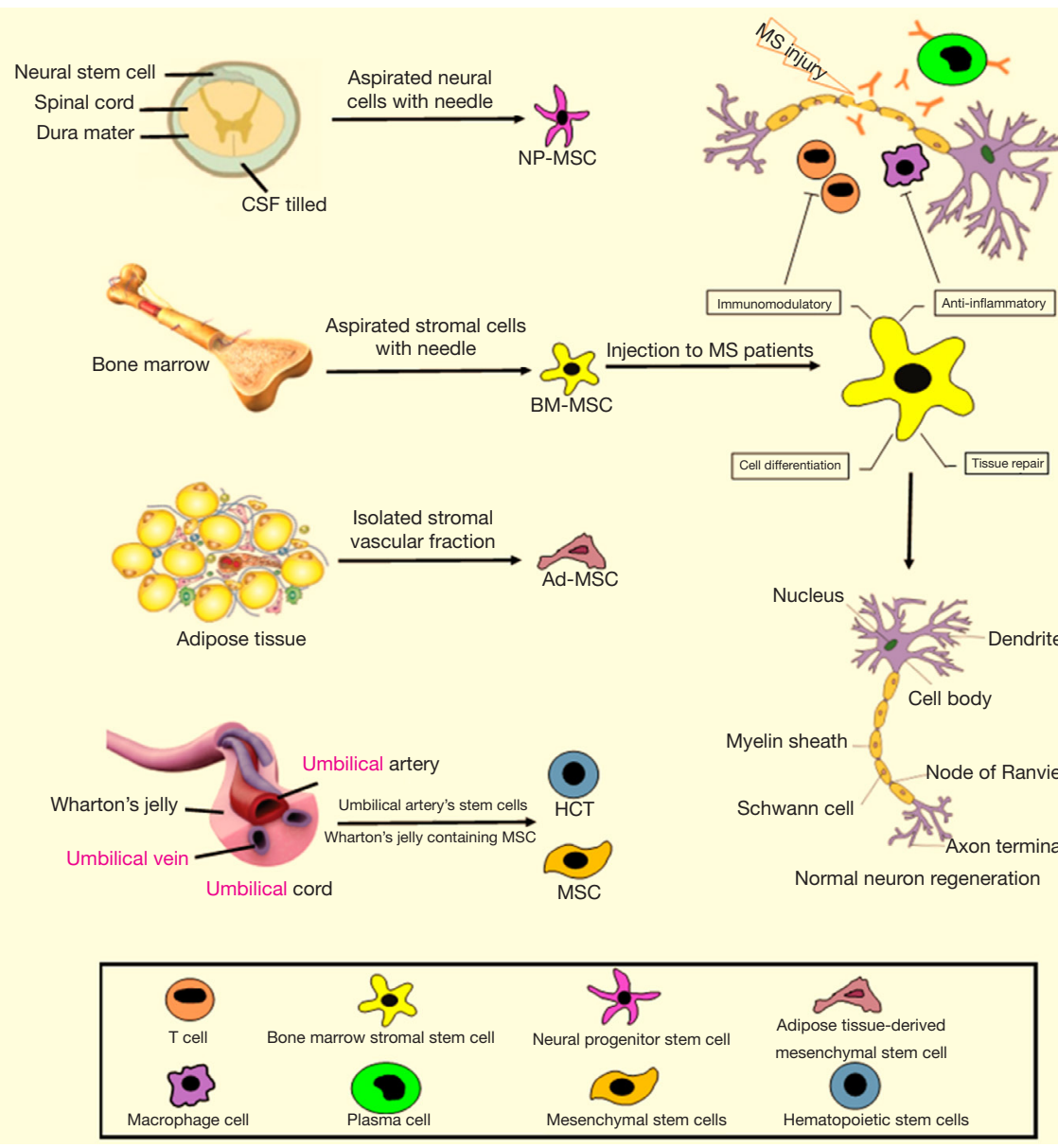

Figure 1 Multiple sclerosis pathophysiology and stem cell Therapy. T cells, B cells and antigen-presenting cells (APCs), including macrophages, enter the central nervous system (CNS), where they secrete certain chemicals known as cytokines that damage the oligodendroglial cells. These cells manufacture the myelin that insulates the neuronal axon. The injured myelin cannot conduct electrical impulses normally, just as a tear in the insulation of a wire leads to a short circuit. Mesenchymal stem cells (MSCs) are isolated from different sources: bone marrow, fat tissues, or umbilical cord. Stromal vascular fraction (SVF) cell therapy; the components of adipose tissue and the key constituents of the SVF pellet are all present in adipose tissue as shown. Following collagenase digestion, incubation in control medium and centrifugation the residual pellet is the so-called SVF. In the new paradigm, the autologous freshly isolated SVF is re-injected into the patient without ex vivo culture, expansion, or differentiation. Umbilical cord; the umbilical cord blood is the most reliable and rich source of Haematopoietic stem cells. The Wharton's jelly found in the umbilical cord tissue is a rich source of MSCs. The uniqueness of these cells lies in the universality of usage. Using one's own Mesenchymal stem cells for treatment is a potentially a new treatment for MS. MS, multiple sclerosis; NP-MSC, mesenchymal stem cell-derived neural progenitors; CSF, cerebrospinal fluid; BM-MSC, bone marrow-derived mononuclear stem cell; ADMSC, adipose-derived mesenchymal stem cell; HCT, hematopoietic cell transplant.

UCMSC in expanded disability status scale (EDSS) scores improvement (Table 4) $(46,47)$. More recently, Riordan et al., have reported the safety and effectiveness of allogeneic UCMSCs injected to MS patients (45). They found that UCMSCs improved neurological parameters such as the Scripps neurological rating scale, EDSS, the nine-hole peg test, the expanded EDSS rating neurologic impairment, and 25-foot walking time in these patients.

\section{Human fetal-derived neural stem cells (hNSCs)}

Several clinical studies have investigated the efficacy and safety of hNSCs in repairing the damage caused by MS. 
Table 1 Mesenchymal stem cells therapy clinical trials for multiple sclerosis disease

\begin{tabular}{|c|c|c|c|c|c|}
\hline Cell type & Years & Country & Phase & Evaluation after cell therapy & $\begin{array}{c}\text { NCT number } \\
\text { (clinicaltrials.gov) }\end{array}$ \\
\hline $\begin{array}{l}\text { Autologous } \\
\text { MSCs }\end{array}$ & 2013 & Italy & $1 \& 2$ & $\begin{array}{l}\text { MSC therapy without side effect infusion. Incidence and severity of } \\
\text { adverse events in MSC treatment group compared to placebo group }\end{array}$ & NCT01854957 \\
\hline $\begin{array}{l}\text { Autologous } \\
\text { MSCs }\end{array}$ & 2011-2018 & Iran & $1 \& 2$ & $\begin{array}{l}\text { Evaluate the effect of mesenchymal stem cell transplantation on } \\
\text { number of Gd positive lesions. Quality-of-life indicators improvement } \\
\text { in MSC compared with placebo group }\end{array}$ & NCT01377870 \\
\hline $\begin{array}{l}\text { Autologous } \\
\text { MSCs }\end{array}$ & 2010-2014 (32) & Spain & 2 & $\begin{array}{l}\text { not identify any serious adverse events, at } 6 \text { months, patients treated } \\
\text { with MSCs had a trend to lower mean cumulative number of GEL, and } \\
\text { at the end of study to reduced mean GEL, non-significant decrease } \\
\text { of the frequency of Th1 }\left(\mathrm{CD} 4^{+} \mathrm{IFN}-\gamma^{+}\right) \text {cells in blood of MSCs treated } \\
\text { patients }\end{array}$ & NCT01228266 \\
\hline $\begin{array}{l}\text { Autologous } \\
\text { MSCs }\end{array}$ & 2011-2016 & USA & 1 & $\begin{array}{l}\text { Evaluated the feasibility of culturing MSCs, and infusion-related safety } \\
\text { and tolerability of autologous MSC transplantation over one month in } \\
\text { patients with relapsing forms of MS, date show that stem cell therapy } \\
\text { safe and not side effect }\end{array}$ & NCT00813969 \\
\hline $\begin{array}{l}\text { Autologous } \\
\text { MSCs }\end{array}$ & 2010-2015 & Spain & $1 \& 2$ & $\begin{array}{l}\text { Evaluated safety and tolerability related to the intravenous infusion } \\
\text { of autologous mesenchymal stem cells. Evaluated effects on MS } \\
\text { disease activity measured by: clinical variables, imaging variables, } \\
\text { immunological and neurophysiologic analysis, neuropsychological } \\
\text { and quality of life scales }\end{array}$ & NCT01056471 \\
\hline
\end{tabular}

MSC, mesenchymal stem cell; Gd, gadolinium; MRI, magnetic resonance imaging; GEL, gadolinium-enhancing lesions; MS, multiple sclerosis.

HNSCs are obtained from brain specimens of several fetal human donors from spontaneous miscarriages occurred after the $8^{\text {th }}$ week after conception (48). Because these cells are the precursors of neuronal cells, they can be considered as one of the best treatments for MS patients. But due to ethical reasons and the lack of the same opportunity to make these cells, it is difficult to use them. A recent study has reported that engrafted hNSCs are able to migrate and differentiate into glial and neuronal subtypes (49). This study demonstrated that hNSCs transplantation can improve cognitive abnormalities in irradiated animals. In a clinical trial, Shin et al. (50) considered the safety and neurological effects of hNSCs injected into the injured cord of patients with traumatic cervical spinal cord injury. Their findings revealed that the hNSCs transplantation is safe and provides neurological benefit for at least one year after transplants.

\section{MSC-derived neural progenitors (MSC-NPs)}

MSC-NPs are an important source of MSCs cells for efficient treatment of MS in preclinical model. Recent study has examined the possibility of MSC-NPs administration to improve CNS repair in MS (51). MSC-NPs showed a consistent gene expression pattern and increased homogeneity to neural commitment. Compared to MSCs, the expression pattern of mesodermal markers and the potential of adipogenic or osteogenic differentiation in MSC-NPs were decreased. This finding suggests the reduced potential of mesodermal differentiation of 
Table 2 Bone marrow-derived MSCs clinical trials for multiple sclerosis disease

\begin{tabular}{|c|c|c|c|c|c|}
\hline Cell type & Years & Country & Phase & Evaluation after cell therapy & $\begin{array}{c}\text { NCT number } \\
\text { (clinicaltrials.gov) }\end{array}$ \\
\hline $\begin{array}{l}\text { Autologous } \\
\text { BM-MSCs }\end{array}$ & 2014-2016 & Israel & 2 & $\begin{array}{l}\text { Changes in immunological response at } 12 \text { months following treatment. } \\
\text { Neurological function test (EDSS) improvement }\end{array}$ & NCT02166021 \\
\hline $\begin{array}{l}\text { Autologous } \\
\text { BM-MSCs }\end{array}$ & 2015-2018 & France & $1 \& 2$ & $\begin{array}{l}\text { Primary outcome is safety cell therapy without side effect. Efficacy } \\
\text { assessed by combined unique MRI activity, volume of GEL, and volume } \\
\text { of } \mathrm{BH}\end{array}$ & NCT02403947 \\
\hline $\begin{array}{l}\text { Autologous } \\
\text { BM-MSCs }\end{array}$ & 2013-2017 & Jordan & $1 \& 2$ & $\begin{array}{l}\text { Patients with any relevant side effects observed, assessing the safety of } \\
\text { autologous mesenchymal stem cells injection }\end{array}$ & NCT01895439 \\
\hline $\begin{array}{l}\text { Autologous } \\
\text { BM-MSCs }\end{array}$ & 2013-2016 & Spain & $1 \& 2$ & $\begin{array}{l}\text { Safety and efficacy after cell therapy, subsequent flow cytometry: IL-2, } 4 \text {, } \\
6 \text {, IFN- } \gamma \text {, IL-10, TNF- } \alpha \text { or by ELISA: TGF- } \beta \text { and IL- } 17\end{array}$ & NCT02035514 \\
\hline $\begin{array}{l}\text { Autologous } \\
\text { BM-MSCs }\end{array}$ & 2017 & Jordan & 1 & $\begin{array}{l}\text { Effectiveness assessment by MRI, safety assessment by physical } \\
\text { examination, vital signs, analytical results, electrocardiograph monitoring, } \\
\text { and EDSS }\end{array}$ & NCT03069170 \\
\hline $\begin{array}{l}\text { Autologous } \\
\text { BM-MNCs }\end{array}$ & 2015-2017 & India & $1 \& 2$ & $\begin{array}{l}\text { Proportion of patients with clinical improvement in EDSS score compared } \\
\text { to baseline. Proportion of patients with a change in either gadolinium } \\
\text { enhancing or new T2-weighted lesions on brain MRI. Proportion of } \\
\text { patients with a change in cognitive function as measured by the PASAT }\end{array}$ & NCT02418351 \\
\hline $\begin{array}{l}\text { Autologous } \\
\text { BM-MSCs }\end{array}$ & $\begin{array}{l}2014-2018 \\
(38)\end{array}$ & UK & 2 & $\begin{array}{l}\text { Bone marrow cell therapy can, as was suggested by the phase I safety } \\
\text { study, improve conduction in multiple central nervous system pathways } \\
\text { affected in progressive MS }\end{array}$ & NCT01815632 \\
\hline $\begin{array}{l}\text { Autologous } \\
\text { PBSCs }\end{array}$ & $\begin{array}{l}2001-2005 \\
(39)\end{array}$ & USA & 1 & $\begin{array}{l}\text { Four new or enhancing lesions were seen on MRI, all within } 13 \text { months } \\
\text { of treatment. In this population with high baseline EDSS, a significant } \\
\text { proportion of patients with advanced MS remained stable for as long as } \\
7 \text { years after transplant. Non-inflammatory events may have contributed } \\
\text { to neurological worsening after treatment }\end{array}$ & NCT00014755 \\
\hline
\end{tabular}

MSCs, mesenchymal stem cells; BM-MSCs, bone marrow-derived mononuclear stem cells; PBSCs, peripheral blood stem cells; MRI, magnetic resonance imaging; GEL, gadolinium-enhancing lesions; $\mathrm{BH}$, black holes (BH); MSCIMS, mesenchymal stem cells in multiple sclerosis; MS, multiple sclerosis; ALS, amyotrophic lateral sclerosis; PASAT, Paced Auditory Serial Addition Test; SAE, serious adverse event; $A E$, adverse event. 
Table 3 Adipose-derived MSCs therapy clinical trials for multiple sclerosis disease

\begin{tabular}{|c|c|c|c|c|c|}
\hline Cell type & Years & Country & Phase & Evaluation after cell therapy & $\begin{array}{l}\text { NCT number } \\
\text { (clinicaltrials.gov) }\end{array}$ \\
\hline $\begin{array}{l}\text { Autologous } \\
\text { ADMSCs }\end{array}$ & $2018(12)$ & Spain & $1 \& 2$ & $\begin{array}{l}\text { Infusion of autologous ADMSCs is safe and feasible in patients } \\
\text { with SPMS }\end{array}$ & NCT01056471 \\
\hline $\begin{array}{l}\text { Autologous } \\
\text { ADMSCs }\end{array}$ & 2012-2015 & Sweden & $1 \& 2$ & $\begin{array}{l}\text { Safety of IV therapy with autologous MSCs in MS patients. } \\
\text { incidence of relapses and disability progression }\end{array}$ & NCT01730547 \\
\hline $\begin{array}{l}\text { Autologous } \\
\text { ASVFs }\end{array}$ & 2014-2018 & USA & 2 & $\begin{array}{l}\text { Change from baseline in sexual satisfaction at month } 12 \text { as measured } \\
\text { by participants using the SSS. Bowel control at month } 12 \text { as measured } \\
\text { by participants using the BWCS. Social support as measured by } \\
\text { participants using the MSSS }\end{array}$ & NCT02157064 \\
\hline
\end{tabular}

MSCs, mesenchymal stem cells; ADMSCs, adipose-derived mesenchymal stem cells; ASVF, adipose stromal vascular fraction; IV, intravenous; MS, multiple sclerosis; SSS, Sexual Satisfaction Scale; BWCS, Bowel Control Scale; MSSS, Modified Medical Outcomes Study Social Support Survey; SF-36, Short Form 36.

Table 4 umbilical cord-derived mesenchymal stem cell therapy for multiple sclerosis disease

\begin{tabular}{|c|c|c|c|c|c|}
\hline Cell type & Years & Country & Phase & Evaluation after cell therapy & $\begin{array}{l}\text { NCT number } \\
\text { (clinicaltrials.gov) }\end{array}$ \\
\hline $\begin{array}{l}\text { Allogeneic } \\
\text { UCMSCs }\end{array}$ & $\begin{array}{l}2014-2017 \\
\quad(45)\end{array}$ & Panama & $1 \& 2$ & $\begin{array}{l}\text { Change in disability as measured by EDSS, quality of life as measured } \\
\text { by the SF- } 36 \text { quality of life questionnaire. Experiencing pulmonary } \\
\text { edema as measured by 12-lead ECG }\end{array}$ & NCT02034188 \\
\hline $\begin{array}{l}\text { Allogeneic } \\
\text { UCMSCs }\end{array}$ & 2010-2014 & China & $1 \& 2$ & $\begin{array}{l}\text { Evaluated core of EDSS, VEP, MRI, SEP and BAEP. Not show any side } \\
\text { effect after cell injection }\end{array}$ & NCT01364246 \\
\hline $\begin{array}{l}\text { Allogeneic } \\
\text { UCMSCs }\end{array}$ & 2015-2017 & $\begin{array}{l}\text { Trinidad and } \\
\text { Tobago }\end{array}$ & $1 \& 2$ & $\begin{array}{l}\text { Clinical improvement is defined as decrease in EDSS score greater } \\
\text { than } 0.5 \text { from baseline }\end{array}$ & NCT02418325 \\
\hline
\end{tabular}

UCMSCs, umbilical cord mesenchymal stem cell; EDSS, Expanded Disability Status Scale; SF-36, Short Form 36; ECG, electrocardiogram; VEP, visual evoked potential; MRI, magnetic resonance imaging; SEP, somatosensory evoked potential; BAEP, brainstem auditory evoked potential; CNS, central nerves system.

MSC-NPs during CNS transplantation. Furthermore, it was identified that MSC-NPs have the ability to enhance the differentiation of oligodendroglial in brainderived neural stem cells which was associated with bioactive factors secretion. These findings indicate that the immunoregulatory activity of MSC-NPs may have therapeutic application for MS disease (52). Experimental studies showed that intrathecal injection of MSC-NPs with experimental allergic encephalitis can improve repair and recovery in MS disease (EAE). Multiple injections of MSC-NPs were associated with a significant improvement in neurological function, while a single injection of MSCNPs had no therapeutic effect on MS disease improvement. MSC-NPs injection was also associated with a significant reduction in area of demyelination and immune cell infiltration, while the number of endogenous nestin-positive progenitor cells was significantly increased in EAE mice. These findings indicate the MSC-NPs positively affect the number of endogenous progenitors in the spinal cord and subsequently improve the repair process. Therefore, these data support the use of autologous MSC-NPs in CNS repairing in patients with MS (53). However, only two 
clinical trial studies used the effectiveness of MSC-NPs in treatment of neural injury in MS patients.

\section{Hematopoietic stem cell}

Hematopoietic stem cell transplantation (HSCT) is a is type of cell-based therapy for hematopoietic disorders (54). HSCT is particularly developed for the treatment of hematological malignancies such as bone marrow failure syndromes, lymphoma, and leukemia (55). Recent investigations have proposed that HSCT can prohibit MS disease progression for $4-5$ years in $70-80 \%$ of patients. This rate is higher than those obtained from the other MS therapies (56). Young patients and those with ambulatory and inflammatory MS activity are most likely to benefit from autologous HSCT are (57). However, further clinical trial studies are necessary to examine the safety, effectiveness, and cost-effectiveness of HSCT on highly active MS drugs $(55,58)$.

Currently, a randomized clinical trial study is investigating the effectiveness of autologous HSCT using a low intensity, non-ablative conditioning regimen with cyclophosphamide and antithymocyte globulin (ATG) compared to treatment with the currently presumed best available immunomodulatory medication (alemtuzumab) in RRMS patients with significant inflammatory disease activity in spite of ongoing immunomodulatory MS treatment (55). If the treatment efficacy of HSCT is better than the currently most efficacious standard, immunomodulatory treatment in randomized treatment trials, HSCT will likely be approved as a part of the standard treatment recommendations for a significant proportion of RRMS patients. A randomized study regarding with statistical power to evaluate the clinical outcome of autologous HSCT compared to a standard immunomodulatory treatment in MS has not yet been published (NCT03477500). Except for Sweden, HSCT is currently not registered as a part of standard MS treatment in the public health services of Europe. The HSCT regimen for the study will be identical to the regimen used in similar patient populations in Sweden, Norway and Denmark.

Clinical trial studies between 2003 and 2014 determined the relationship between non-myeloablative HSCT and neurological disability and other clinical findings in MS patients (59). Data showed that EDSS score was significantly improved from a pretransplant median of 4.0 to 3.0. Additionally, the neurologic rating scale score was significantly improved from a pretransplant median of 74 to 88.0. Interestingly, total quality-of-life score was significantly increased from 46 to 64 . Table 5 shows all clinical trials that investigated the effectiveness of HSCT for MS disease.

\section{Conclusions}

MS is an autoimmune disease and complex disorder of the CNS which is associated with the loss of axon basically long-term progressive disability. Unfortunately, there is no effective therapeutic method for MS disease and current medications can only manage and relieve the progress of the disease but not treat it thoroughly. Recent investigations have shown that cell-based therapies are able to repair CNS and can protect it against inflammatory responses caused by immune system (65). Cell-based therapies have provided a new window for the prevention and treatment of different neurodegenerative diseases such as MS, Parkinson's disease (PD), Alzheimer's and amyotrophic lateral sclerosis (ALS). The efficacy and safety of different stem cells have been determined and reported by several clinical trials. It is well-documented that most of the stem cells used to treat MS disease are adult MSCs due to their safety and easily extraction methods. Bone marrow is the major source of MSCs. The UC stem cells are also a good option for MS treatment because of their multipotent and highly differentiated potential. However, a cell bank is needed to supply and maintain these cells. Adult adipose tissue stem cells are one of the most suitable cells for MS treatment. Firstly, the separation of the adipose tissue is easy and can be provided from different parts of the body. Secondly, the amount of stem cells produced per unit area is high and during a sampling of the adipose tissue, a large number of stem cells can be isolated. Thirdly, the cost of stem cell transfusion from the adipose tissue is not expensive. Meanwhile, adipose MSCs, such as the adult stem cell group, are very safe to use. These advantageous make the ASCs as an appropriate candidate for the treatment of MS. HSCs are the other types of stem cell which have been used in several trials for MS treatment and caused significant improvements in quality-of-life, neurologic disability, and functional scores after cell therapy (64). Neuronal stem cells are a potential source of highly digestible semidifferentiated cells which can be rapidly replaced by damaged neuronal cells. However, this method requires a number of aborted fetuses that make it very difficult for the production of neuronal stem cells. 
Table 5 Hematopoietic stem cell transplantation for multiple sclerosis disease

\begin{tabular}{|c|c|c|c|c|c|}
\hline Cell type & Years & Country & Phase & Evaluation after cell therapy & $\begin{array}{l}\text { NCT number } \\
\text { (clinicaltrials.gov) }\end{array}$ \\
\hline $\begin{array}{l}\text { Autologous } \\
\text { HSCs }\end{array}$ & 2007-2018 & Switzerland & $1 \& 2$ & $\begin{array}{l}\text { Safe delivery of hematopoietic stem cell after infusion. Stem cell } \\
\text { engraftment and disease remission after } 3 \text { years }\end{array}$ & NCT00497952 \\
\hline $\begin{array}{l}\text { Autologous } \\
\text { HSCs }\end{array}$ & 2015 & Philippines & 1 & $\begin{array}{l}\text { Safety and efficacy after cell therapy, measurement of quality of life by } \\
\text { change in baseline of RAND- } 36 \text { score }\end{array}$ & NCT03113162 \\
\hline $\begin{array}{l}\text { Autologous } \\
\text { HSCs }\end{array}$ & $\begin{array}{l}2016-2018 \\
(60)\end{array}$ & Mexico & 1 & $\begin{array}{l}\text { There were no transplant-related deaths and the } 128 \text {-month overall } \\
\text { survival of the patients is } 100 \% \text {. In } 82 \text { persons followed up for } 3 \text { or } \\
\text { more months, the Expanded Disability Status Scale diminished from } \\
\text { a mean of } 5.2 \text { to } 4.9 \text {, the best results being obtained in relapsing- } \\
\text { remitting and primary progressive MS }\end{array}$ & NCT02674217 \\
\hline $\begin{array}{l}\text { Autologous } \\
\text { HSCs }\end{array}$ & 2018 & Norway & 3 & $\begin{array}{l}\text { Proportion of patients with no evidence of disease activity, difference } \\
\text { in patient reported quality of life based on the EuroQoL Health Related } \\
\text { Quality of Life- } 5 \text { Dimensions- } 5 \text { Levels (EQ-5D } 5 \mathrm{~L} \text { ) scores, time to first } \\
\text { sign of new disease activity, as measured as new relapses, EDSS- } \\
\text { progression, MRI-activity or brain atrophy }\end{array}$ & NCT03477500 \\
\hline $\begin{array}{l}\text { Autologous } \\
\text { HSCs }\end{array}$ & 2012-2013 & USA & 2 & $\begin{array}{l}\text { Effectiveness of high dose chemotherapy with HPC transplant } \\
\text { for multiple sclerosis that has failed at least two lines of therapy, } \\
\text { Subsequent MRI scan will be determined by the patient's neurologist } \\
\text { as is needed clinically. }\end{array}$ & NCT01679041 \\
\hline $\begin{array}{l}\text { Autologous } \\
\text { HSCs }\end{array}$ & $\begin{array}{l}2006-2017 \\
(64)\end{array}$ & USA & 2 & $\begin{array}{l}\text { Overall event-free survival was } 78.4 \% \text { at } 3 \text { years. Progression-free } \\
\text { survival and clinical relapse-free survival were } 90.9 \% \text { and } 86.3 \% \text {, } \\
\text { respectively. Adverse events were consistent with expected toxic } \\
\text { effects associated with HDIT/HCT, and no acute treatment-related } \\
\text { neurologic adverse events were observed. Improvements were noted } \\
\text { in neurologic disability, quality-of-life, and functional scores }\end{array}$ & NCT00288626 \\
\hline $\begin{array}{l}\text { Autologous } \\
\text { HSCs }\end{array}$ & $2002-2007$ & USA & 2 & $\begin{array}{l}\text { HSC therapy is safe without side effect after cell injection. EDSS } \\
\text { measure after cell therapy }\end{array}$ & NCT00040482 \\
\hline $\begin{array}{l}\text { Autologous } \\
\text { HSCs }\end{array}$ & 2017 & USA & 3 & $\begin{array}{l}\text { Survival of participants after cell therapy. EDSS Improvement. } \\
\text { Supportive confirmation by enhancement on MRI is preferred }\end{array}$ & NCT03342638 \\
\hline
\end{tabular}

HSCs, hematopoietic stem cells; EDSS, Expanded Disability Status Scale; MS, multiple sclerosis; MRI, magnetic resonance imaging; HPC, hematopoietic progenitor cells; FIS, Fatigue Impact Scale; HSCT, hematopoietic stem cell transplantation; CNS, central nervous system; HDIT, high-dose immunosuppressive therapy; HCT, hematopoietic cell transplant; HSC, hematopoietic stem cell. 


\section{Acknowledgments}

We would like to thanks all staffs and member who helped us. There was no financial support for this review work.

\section{Footnote}

Conflicts of Interest: The authors have no conflicts of interest to declare.

Ethical Statement: The authors are accountable for all aspects of the work in ensuring that questions related to the accuracy or integrity of any part of the work are appropriately investigated and resolved.

\section{References}

1. Goldenberg MM. Multiple sclerosis review. P T 2012;37:175-84.

2. Burkill S, Montgomery S, Kockum I, et al. The association between multiple sclerosis and pain medications. Pain 2019;160:424-32.

3. Simacek KF, Ko JJ, Moreton D, et al. The Impact of Disease-Modifying Therapy Access Barriers on People With Multiple Sclerosis: Mixed-Methods Study. J Med Internet Res 2018;20:e11168.

4. Matza LS, Kim K, Phillips G, et al. Multiple sclerosis relapse: Qualitative findings from clinician and patient interviews. Mult Scler Relat Disord 2019;27:139-46.

5. Ginestal-Lopez RC. Immunotherapy for neurological diseases, present and future. Farm Hosp 2018;42:251-60.

6. Tandon A, Singh SJ, Chaturvedi RK. Stem Cells as Potential Targets of Polyphenols in Multiple Sclerosis and Alzheimer's Disease. Biomed Res Int 2018;2018:1483791.

7. Retraction: The Role of Stem Cell Therapy in Multiple Sclerosis: An Overview of the Current Status of the Clinical Studies. Adv Biomed Res 2018;7:129.

8. Weiss JN, Levy S. Stem Cell Ophthalmology Treatment Study (SCOTS): bone marrow derived stem cells in the treatment of Usher syndrome. Stem Cell Investig 2019;6;31.

9. von Wunster B, Bailey S, Wilkins A, et al. Advising patients seeking stem cell interventions for multiple sclerosis. Pract Neurol 2018;18:472-6.

10. Neal EG, Liska MG, Lippert T, et al. An update on intracerebral stem cell grafts. Expert Rev Neurother 2018;18:557-72.

11. Rush CA, Atkins HL, Freedman MS. Autologous
Hematopoietic Stem Cell Transplantation in the Treatment of Multiple Sclerosis. Cold Spring Harb Perspect Med 2019. doi: 10.1101/cshperspect.a029082.

12. Fernandez O, Izquierdo G, Fernandez V, et al. Adiposederived mesenchymal stem cells (AdMSC) for the treatment of secondary-progressive multiple sclerosis: A triple blinded, placebo controlled, randomized phase I/II safety and feasibility study. PLoS One 2018;13:e0195891.

13. Planchon SM, Lingas KT, Reese Koc J, et al. Feasibility of mesenchymal stem cell culture expansion for a phase I clinical trial in multiple sclerosis. Mult Scler J Exp Transl Clin 2018;4:2055217318765288.

14. Jiang H, Zhang Y, Tian K, et al. Amelioration of experimental autoimmune encephalomyelitis through transplantation of placental derived mesenchymal stem cells. Sci Rep 2017;7:41837.

15. Bowles AC, Scruggs BA, Bunnell BA. Mesenchymal stem cell-based therapy in a mouse model of experimental autoimmune encephalomyelitis (EAE). Methods Mol Biol 2014;1213:303-19.

16. Mahfouz MM, Abdelsalam RM, Masoud MA, et al. The neuroprotective effect of mesenchymal stem cells on an experimentally induced model for multiple sclerosis in mice. J Biochem Mol Toxicol 2017. doi: 10.1002/jbt.21936.

17. Loma I, Heyman R. Multiple sclerosis: pathogenesis and treatment. Curr Neuropharmacol 2011;9:409-16.

18. Coret F, Perez-Miralles FC, Gascon F, et al. Onset of secondary progressive multiple sclerosis is not influenced by current relapsing multiple sclerosis therapies. Mult Scler J Exp Transl Clin 2018;4:2055217318783347.

19. Derwenskus J. Current disease-modifying treatment of multiple sclerosis. Mt Sinai J Med 2011;78:161-75.

20. Minagar A. Current and future therapies for multiple sclerosis. Scientifica (Cairo) 2013;2013:249101.

21. Smith B, Carson S, Fu R, et al. Drug Class Review: Disease-modifying Drugs for Multiple Sclerosis: Final Update 1 Report. Drug Class Reviews. Portland (OR): Oregon Health \& Science University; 2010 Aug.

22. Zhang J, Shi S, Zhang Y, et al. Alemtuzumab versus interferon beta 1a for relapsing-remitting multiple sclerosis. Cochrane Database Syst Rev 2017;11:CD010968.

23. Arroyo Gonzalez R, Kita M, Crayton H, et al.

Alemtuzumab improves quality-of-life outcomes compared with subcutaneous interferon beta-1a in patients with active relapsing-remitting multiple sclerosis. Mult Scler 2017;23:1367-76.

24. Hu X, Shang S, Nestorov I, et al. COMPARE: Pharmacokinetic profiles of subcutaneous peginterferon 
beta-1a and subcutaneous interferon beta-1a over 2 weeks in healthy subjects. Br J Clin Pharmacol 2016;82:380-8.

25. Genc B, Bozan HR, Genc S, et al. Stem Cell Therapy for Multiple Sclerosis. Adv Exp Med Biol 2019;1084:145-74.

26. Xiao J, Yang R, Biswas S, et al. Mesenchymal stem cells and induced pluripotent stem cells as therapies for multiple sclerosis. Int J Mol Sci 2015;16:9283-302.

27. Baldassari LE, Cohen JA. Mesenchymal Stem Cell-derived Neural Progenitor Cells in Progressive Multiple Sclerosis: Great Expectations. EBioMedicine 2018;29:5-6.

28. Meamar R, Nematollahi S, Dehghani L, et al. The role of stem cell therapy in multiple sclerosis: An overview of the current status of the clinical studies. Adv Biomed Res 2016;5:46.

29. Nejad-Moghaddam A, Ajdary S, Tahmasbpour E, et al. Immunomodulatory Properties of Mesenchymal Stem Cells Can Mitigate Oxidative Stress and Inflammation Process in Human Mustard Lung. Biochem Genet 2016;54:769-83.

30. Lu Q, El-Hashash AHK. Cell-based therapy for idiopathic pulmonary fibrosis. Stem Cell Investig 2019;6:22.

31. Nejad-Moghaddam A, Tahmasbpour E, Sohrabiyan M, et al. Stem cells therapy: a review on approaches that can be used for treatment of respiratory failures in sulfur mustardinjured patients. Immunopharmacol Immunotoxicol 2018;40:359-67.

32. Llufriu S, Sepulveda M, Blanco Y, et al. Randomized placebo-controlled phase II trial of autologous mesenchymal stem cells in multiple sclerosis. PLoS One 2014;9:e113936.

33. Nejad-Moghaddam A, Panahi Y, Abdollahpour Alitappeh M, et al. Therapeutic Potential of Mesenchymal Stem Cells for the Treatment of Airway Remodeling in Pulmonary Diseases. Iran J Allergy Asthma Immunol 2015;14:552-68.

34. Connick P, Kolappan M, Crawley C, et al. Autologous mesenchymal stem cells for the treatment of secondary progressive multiple sclerosis: an open-label phase 2a proof-of-concept study. Lancet Neurol 2012;11:150-6.

35. Connick P, Kolappan M, Patani R, et al. The mesenchymal stem cells in multiple sclerosis (MSCIMS) trial protocol and baseline cohort characteristics: an open-label pre-test: post-test study with blinded outcome assessments. Trials 2011;12:62.

36. Karussis D, Karageorgiou C, Vaknin-Dembinsky A, et al. Safety and immunological effects of mesenchymal stem cell transplantation in patients with multiple sclerosis and amyotrophic lateral sclerosis. Arch Neurol
2010;67:1187-94.

37. Rice CM, Marks DI, Walsh P, et al. Repeat infusion of autologous bone marrow cells in multiple sclerosis: protocol for a phase I extension study (SIAMMS-II). BMJ Open 2015;5:e009090.

38. Rice CM, Marks DI, Ben-Shlomo Y, et al. Assessment of bone marrow-derived Cellular Therapy in progressive Multiple Sclerosis (ACTiMuS): study protocol for a randomised controlled trial. Trials 2015;16:463.

39. Bowen JD, Kraft GH, Wundes A, et al. Autologous hematopoietic cell transplantation following highdose immunosuppressive therapy for advanced multiple sclerosis: long-term results. Bone Marrow Transplant 2012;47:946-51.

40. Klinker MW, Wei CH. Mesenchymal stem cells in the treatment of inflammatory and autoimmune diseases in experimental animal models. World J Stem Cells 2015;7:556-67.

41. Stepien A, Dabrowska NL, Maciagowska M, et al. Clinical Application of Autologous Adipose Stem Cells in Patients with Multiple Sclerosis: Preliminary Results. Mediators Inflamm 2016;2016:5302120.

42. Nejad-Moghaddam A, Ajdari S, Tahmasbpour E, et al. Adipose-Derived Mesenchymal Stem Cells for Treatment of Airway Injuries in A Patient after Long-Term Exposure to Sulfur Mustard. Cell J 2017;19:117-26.

43. Chao KC, Chao KF, Fu YS, et al. Islet-like clusters derived from mesenchymal stem cells in Wharton's Jelly of the human umbilical cord for transplantation to control type 1 diabetes. PLoS One 2008;3:e1451.

44. Liu R, Zhang Z, Lu Z, et al. Human umbilical cord stem cells ameliorate experimental autoimmune encephalomyelitis by regulating immunoinflammation and remyelination. Stem Cells Dev 2013;22:1053-62.

45. Riordan NH, Morales I, Fernandez G, et al. Clinical feasibility of umbilical cord tissue-derived mesenchymal stem cells in the treatment of multiple sclerosis. J Transl Med 2018;16:57.

46. Lublin FD, Bowen JD, Huddlestone J, et al. Human placenta-derived cells (PDA-001) for the treatment of adults with multiple sclerosis: a randomized, placebocontrolled, multiple-dose study. Mult Scler Relat Disord 2014;3:696-704.

47. Li JF, Zhang DJ, Geng T, et al. The potential of human umbilical cord-derived mesenchymal stem cells as a novel cellular therapy for multiple sclerosis. Cell Transplant 2014;23 Suppl 1:S113-22.

48. Lee H, Yun S, Kim IS, et al. Human fetal brain-derived 
neural stem/progenitor cells grafted into the adult epileptic brain restrain seizures in rat models of temporal lobe epilepsy. PLoS One 2014;9:e104092.

49. Acharya MM, Christie LA, Hazel TG, et al. Transplantation of human fetal-derived neural stem cells improves cognitive function following cranial irradiation. Cell Transplant 2014;23:1255-66.

50. Shin JC, Kim KN, Yoo J, et al. Clinical Trial of Human Fetal Brain-Derived Neural Stem/Progenitor Cell Transplantation in Patients with Traumatic Cervical Spinal Cord Injury. Neural Plast 2015;2015:630932.

51. Harris VK, Stark J, Vyshkina T, et al. Phase I Trial of Intrathecal Mesenchymal Stem Cell-derived Neural Progenitors in Progressive Multiple Sclerosis. EBioMedicine 2018;29:23-30.

52. Harris VK, Faroqui R, Vyshkina T, et al. Characterization of autologous mesenchymal stem cell-derived neural progenitors as a feasible source of stem cells for central nervous system applications in multiple sclerosis. Stem Cells Transl Med 2012;1:536-47.

53. Harris VK, Yan QJ, Vyshkina T, et al. Clinical and pathological effects of intrathecal injection of mesenchymal stem cell-derived neural progenitors in an experimental model of multiple sclerosis. J Neurol Sci 2012;313:167-77.

54. Hatzimichael E, Tuthill M. Hematopoietic stem cell transplantation. Stem Cells Cloning 2010;3:105-17.

55. Massey JC, Sutton IJ, Ma DDF, et al. Regenerating Immunotolerance in Multiple Sclerosis with Autologous Hematopoietic Stem Cell Transplant. Front Immunol 2018;9:410.

56. Muraro PA, Martin R, Mancardi GL, et al. Autologous haematopoietic stem cell transplantation for treatment of multiple sclerosis. Nat Rev Neurol 2017;13:391-405.

57. Muraro PA, Pasquini M, Atkins HL, et al. Long-term Outcomes After Autologous Hematopoietic Stem Cell

doi: $10.21037 /$ sci.2019.10.06

Cite this article as: Jafarzadeh Bejargafshe $M$, Hedayati M, Zahabiasli S, Tahmasbpour E, Rahmanzadeh S, NejadMoghaddam A. Safety and efficacy of stem cell therapy for treatment of neural damage in patients with multiple sclerosis. Stem Cell Investig 2019;6:44.
Transplantation for Multiple Sclerosis. JAMA Neurol 2017;74:459-69.

58. Bakhuraysah MM, Siatskas C, Petratos S. Hematopoietic stem cell transplantation for multiple sclerosis: is it a clinical reality? Stem Cell Res Ther 2016;7:12.

59. Burt RK, Balabanov R, Han X, et al. Association of nonmyeloablative hematopoietic stem cell transplantation with neurological disability in patients with relapsingremitting multiple sclerosis. JAMA 2015;313:275-84.

60. Ruiz-Arguelles GJ, Leon-Pena AA, Leon-Gonzalez M, et al. A Feasibility Study of the Full Outpatient Conduction of Hematopoietic Transplants in Persons with Multiple Sclerosis Employing Autologous Non-Cryopreserved Peripheral Blood Stem Cells. Acta Haematol 2017;137:214-9.

61. Bose G, Atkins HL, Bowman M, et al. Autologous hematopoietic stem cell transplantation improves fatigue in multiple sclerosis. Mult Scler 2019;25:1764-72.

62. Atkins HL, Bowman M, Allan D, et al. Immunoablation and autologous haemopoietic stem-cell transplantation for aggressive multiple sclerosis: a multicentre single-group phase 2 trial. Lancet 2016;388:576-85.

63. Burman J, Fransson M, Totterman TH, et al. T-cell responses after haematopoietic stem cell transplantation for aggressive relapsing-remitting multiple sclerosis. Immunology 2013;140:211-9.

64. Nash RA, Hutton GJ, Racke MK, et al. High-dose immunosuppressive therapy and autologous hematopoietic cell transplantation for relapsing-remitting multiple sclerosis (HALT-MS): a 3-year interim report. JAMA Neurol 2015;72:159-69.

65. Shroff G. A review on stem cell therapy for multiple sclerosis: special focus on human embryonic stem cells. Stem Cells Cloning 2018;11:1-11. 